\title{
Analyzing EFL Learners' Factors in Affecting English Pronunciation and The Distribution of Pronunciation Rating: A Qualitative Study
}

\author{
${ }^{* 1}$ Ikrar Genidal Riadil, ${ }^{2}$ Rolisda Yosintha \\ ${ }^{* 1}$ Universitas Tidar, Magelang, Indonesia, ikrargenida121@gmail.com \\ ${ }^{2}$ Universitas Tidar, Magelang, Indonesia, rolisda@untidar.ac.id
}

Submitted: 10/03/2021 Revised: 16/04/2021 Accepted: 18/05/2021

How to cite this article: Riadil, I.G. \& Yosintha, R. (2021). Analyzing EFL learners' factors in affecting English pronunciation and the distribution of pronunciation rating: A Qualitative Study. IJELR: International Journal of Education, Language, and Religion, 3(1), 1-8.

\begin{abstract}
Pronunciation is the production of speech sounds for communication. It is the most difficult area of English. Pronunciation teaching in English as a Foreign Language (EFL) curriculum has also been ignored for many factors. As a result, numerous EFL learners have often found it challenging to speak freely because of their weak pronunciation. This study deals with the Teaching English as a Foreign Language (TEFL) of speaking skill in EFL Learners of Indonesia. The researcher used qualitative research. There were thirty-five students who filled the questionnaire and ten students read text given First, the researcher looked for the questionnaire and found the questionnaire about Willingness to communicate. Second, the findings of tense were analyzed to know what factors that affect Indonesian learners' English pronunciation. Third, the findings were shown into tables to know the factors. Then, the researcher asked ten learners to record when they read the text given (reading passage). After that, the researcher analyzed the pronunciation rating based on the trusted rating sheets. Finally, the researcher drew a conclusion based on the findings and discussion. This study is to investigate the factors affecting Indonesian students' pronunciation and the distribution of pronunciation rating. The study seeks to answer two research questions (RQ): (RQ1) What are the factors affecting Indonesian learners' English Pronunciation? and (RQ2) What are the distributions of Pronunciation Rating? This study adopted a descriptive qualitative approach which used questionnaire to build this research and reading passage. In conclusion, the researcher elaborated and answered the research questions, and explained the results and discussions about the type of factors that affect EFL learners' in English pronunciation.
\end{abstract}

\section{Keywords}

EFL Learners factors; English pronunciation; pronunciation rating; TEFL; teaching pronunciation

\section{Introduction}

Language is a pivotal aspect of human being. By learning language, people can communicate with each other, get information from one to another and interact (Riadil, 2020). Language has a big role in human life to make a relation in their environment (Riadil, 2020). One of the experts' states that 
language is used widely in communication between people who do not share the same first (or even second) language (Harmer, 2007). It indicates that language is very crucial to learn in human life.

English appears as one of international languages used to communicate among people all over the world. The use of English in nonnative country can be divided into two English as the second language and English as foreign language (EFL). One of the countries who applied English as foreign language is Indonesia. In EFL country, English is used for some purposes such as education, business, etc. Related to the education function, English is taught in the school started from elementary school.

Unfortunately, in actual fact, it is still challenging for Indonesian students to practice their English skills on a daily basis, even though they have been studying English for ten years in formal junior high school, high school and university because they might get a good score of English on their report card, but they cannot yet speak good English (Musthafa, 2001). It is the truth that many English as a Foreign Language ( EFL) educators lament about their speaking courses, of which a large amount of students do not take integral roles of speaking exercises (Abadi, 2015).

Many factors may affect students negatively in taking part in speaking activities during the teaching experience (Riadil, 2020). First, the large numbers of students which usually consist of 30-35 students or more become problematic. Such section provides fewer opportunities for them to practice speaking. Richards \& Schmidt (2010) states that class size affects the quality of instruction in which it should not exceed fifteen for most language classes.

Besides, students prefer to disguise their faults as well as shortcomings in order to shield them from getting chuckled at. As a result, they are not able to learn English. Enough that, the less they practice, the less they enhance their speaking skills, and the more they are frightened to do so. Last but not least, most teachers prefer to teach grammar to productive skills such as speaking and writing. This is supported by Musthafa (2001) explained that many teachers in Asia tend to focus their teaching on grammatical items and knowledge of syntax.

In this era many students of English Department at Tidar University still shy to speak English on campus. Some of them only speak English in a special event. Sometimes, they speak English to their lecturers. Some students also speak English with their certain friends in the English Department. English is originally the language from United Kingdom. It was expanded to other countries such as United States, Australia, Canada, so on, as their first language. Therefore, English also used widely across the globe as second language and foreign language. It makes English becomes an International language. Consequently, the needs of English skills to be fulfil is high especially in speaking skill.

\section{Teaching Speaking}

Speaking skill in English as a foreign language (EFL) such as Indonesia becomes an important part in the daily life to support the digital era. In this era, people tend to learn English for communication or speaking skill rather than the other skills. However, speaking in a foreign language is often seen by people especially learners as the most challenging skill among other skills, since speaking and writing involve language production and it is called as productive skills (Andrade et al, 2018).

In order to fulfill the highly demand of English speaker, English becomes an important subject at school. Therefore, the right strategy in teaching speaking is needed to develop learners' speaking skill. The teachers have tried to look for the way to help students in their effort to be successful in learning a foreign language (Abdullah et al, 2019).

\section{Teaching Pronunciation}

Teaching pronunciation is different from the teaching other skills because it also involves the motor skills (Hollins, 2011). The teacher needs to show the student how to pronounce words correctly using 
the articulation. The teacher has to differ the vowels and consonants. The example is they need to be aware of the varying position of the jaw or how to pronounce the voiceless consonants.

People in English as a foreign language country often do not improve their pronunciation. Even though, they can speak by using their own mother tongue but they need to improve their pronunciation. It is allowed to speak with their own accent, but still considering their good pronunciation. When they pronounce correctly, the listener will understand well. The important is the same of learning to understand when people speak with different accents in natural condition (Gilakjani, 2016). One of the primary goals in teaching pronunciation is the intelligible pronunciation which is not perfect but is can be understood (Gilakjani, 2016).

This study aims to investigate the factors affecting Indonesian learners' English pronunciation. Afterward, the researcher have adapted from (Doqaruni, 2015). The researcher formulates two research questions (RQ): (RQ1) What are the factors affecting Indonesian learners' English Pronunciation? and (RQ2) What is/are the distributions of Pronunciation Rating?

\section{Method}

Qualitative research was used in this research. Patton \& Cochran (2007) explained qualitative research is characterized by its aims, which relate to understanding some aspect of social life, and its methods which generate words, rather than numbers, as data for analysis. Qualitative research is understanding of social phenomenon based on participant's point of view. In order to increase information into a certain phenomenon, such as an environment, a process, or a belief. The data was obtained by sending questionnaires to the respondents. The data collection techniques for this analysis were begun by providing the questionnaire, asking the respondents to fill out the questionnaire and eventually collecting the questionnaire that had been replied by the investigator.

This method was influenced by (Cam \& Tran, 2017) in (Riadil, 2020). After the data had been collected, it would be analyzed and recognized. Like what Cam \& Tran (2017) stated that the questionnaire was a quite useful collection method because researcher could reach many participants and respondents in a short time and it did not need cost so much.

The aims of this study were to know the factors that affect Indonesian learners' (EFL) English pronunciation in the daily life and how are the distributions of pronunciation rating, therefore this study was rated using a descriptive qualitative approach. Qualitative data speaks louder than a human's experience (Mitchell \& Clark, 2018). The written word is important to be conducted in qualitative research to spread the findings (Riadil et al, 2019). Qualitative research produces a different understanding by humans in a context and the way they see the results (Pramjit \& Dhillon, 2016). The researcher conducted questionnaire which was taken from Hwang (2008) article entitled "Factors affecting Korean learners' English pronunciation and comprehensibility" which to investigate the factors that affect Korean learner's English pronunciation which Korea and Indonesia are the same as a foreign language country. Hwang (2008) also researched about the comprehensibility of pronunciation. The researcher also conducted an analysis using voice note from various learners to gain the information about the pronunciation rating.

The objects of this research were students of fifth semester. They were EFL learners from English Department students of Tidar University. There were thirty-five students who filled the questionnaire and ten students read text given. There were twenty questions in the questionnaire that needed to be answered. The questionnaire was conducted through online media which did not need name. The media was Google form which can be accessed by everyone who has the link. There were thirty-five students who gave their own responses without being pressed. Therefore, this research was conducted 
as a students' perspective analysis to communicate with English in the English class, the researcher used the questionnaire from an existing research.

To begin the study, the researcher described the English as international language, the perspective of teaching speaking, and the different between teaching pronunciation with the other skills. This research focused on students' own perspective to communicate with English, then the researcher gave the explanations about teaching speaking and teaching pronunciation according to several experts. The researcher looked for the questionnaire from an existing research and made them through online from maker with Google Form. The title of the form was Factors Affecting Indonesian Learners' English Pronunciation. After making online questionnaire, the researcher shared the link of the questionnaire to the learners. Learners who are willing to fill the form can access it and answer the questions according their own feeling, perspective, and knowledge. In the next part of the study, the researcher collected the results of the questionnaire. Then the results were analyzed by using the trusted theories. In this process, the researcher used three steps of analyzing, First, the researcher looked for the questionnaire and found the questionnaire about Willingness to communicate. Second, the findings of tense were analyzed to know what factors that affect Indonesian learners' English pronunciation. Third, the findings were shown into tables to know the factors. Then, the researcher asked ten learners to record when they read the text given (reading passage). After that, the researcher analyzed the pronunciation rating based on the trusted rating sheets. Finally, the researcher drew a conclusion based on the findings and discussion.

\section{Results and Discussion}

This part deliberates the results of this study. It consists of two-parts; the first part is about the factors affecting Indonesian learners' English pronunciation according to the questionnaire conducted. The second part is the distribution of pronunciation rating.

\section{Factors}

According to Pramjit \& Dhillon (2016) the most influential factor that affects a learner's pronunciation is native language. Many new English speakers especially in EFL still use their own mother tongue to pronounce word. Therefore, here are some subjects' English exposure that influence Indonesian learners' English pronunciation based on the questionnaire given.

Table 1. The questionnaire results frequency in English major as English exposure

\begin{tabular}{clcccc}
\hline \multicolumn{1}{c}{ No } & \multicolumn{1}{c}{ Statements } & $\begin{array}{c}\text { Strongly } \\
\text { Agree }\end{array}$ & Agree & Disagree & $\begin{array}{c}\text { Strongly } \\
\text { Disagree }\end{array}$ \\
\hline Statement 1 & I study English to get a better job. & $40 \%$ & $54.30 \%$ & $5.70 \%$ & $0 \%$ \\
\hline Statement 2 & I study English to get a good grade. & $34.30 \%$ & $40 \%$ & $22.90 \%$ & $2.90 \%$ \\
\hline Statement 3 & I study English to study abroad. & $28.60 \%$ & $45.70 \%$ & $25.70 \%$ & $0 \%$ \\
\hline Statement 4 & $\begin{array}{l}\text { I study English to prepare for living in an } \\
\text { English-speaking country. }\end{array}$ & $28.60 \%$ & $51.40 \%$ & $20 \%$ & $0 \%$ \\
\hline Statement 5 & $\begin{array}{l}\text { I study English to communicate freely with } \\
\text { native speakers of English. }\end{array}$ & $40 \%$ & $57.10 \%$ & $2.90 \%$ & $0 \%$ \\
\hline Statement 6 & $\begin{array}{l}\text { I study English for cultural exchange with } \\
\text { native speakers of English. }\end{array}$ & $22.90 \%$ & $54.30 \%$ & $22.90 \%$ & $0 \%$ \\
\hline
\end{tabular}

Through the questionnaire, in the context of English major, revealed that most of Indonesian learner study English to get a good grade in order to get a better job. Zein, (2017) stated that completion of study English with higher proficiency was considered for more job opportunities. It is true since in this era, digital era, Indonesians are prepared to face that era. While, most of them also study English to prepare the opportunity so go abroad especially in an English-speaking country such as United Kingdom or United States. 
Table 2. The questionnaire results frequency of private English education

\begin{tabular}{llcccc}
\hline No & Statements & $\begin{array}{c}\text { Strongly } \\
\text { Agree }\end{array}$ & Agree & Disagree & $\begin{array}{c}\text { Strongly } \\
\text { Disagree }\end{array}$ \\
\hline Statement 1 & $\begin{array}{l}\text { I spend a great amount of time and money } \\
\text { on English study. }\end{array}$ & $9 \%$ & $57.10 \%$ & $31.40 \%$ & $3 \%$ \\
\hline Statement 2 & I enjoy learning and using English. & $25.70 \%$ & $69 \%$ & $5.70 \%$ & $2.90 \%$ \\
\hline
\end{tabular}

Based on the private English education in table 2, 65.7\% learners agree that they have spent a great amount of time and money on English study. Indonesians study English since elementary school, the first-grade until at least twelve-grade of senior high school. It can be calculated that they need twelve years to learn English. With more than one decade, they have spent much money. In these years, learners seem to enjoy their time in learning English and speaking with English to friends.

Table 3. The questionnaire results frequency of Living with NSs of English

\begin{tabular}{llcccc}
\hline No & Statements & Strongly Agree & Agree & Disagree & $\begin{array}{l}\text { Strongly } \\
\text { Disagree }\end{array}$ \\
\hline Statement 1 & $\begin{array}{l}\text { I prefer native speakers of English as English } \\
\text { teachers. }\end{array}$ & $20 \%$ & $45.70 \%$ & $34.30 \%$ & $0 \%$ \\
\hline Statement 2 & $\begin{array}{l}\text { I prefer talking to native speakers of English over } \\
\text { non-native speakers. }\end{array}$ & $11.40 \%$ & $51 \%$ & $37.10 \%$ & $0.00 \%$ \\
\hline Statement 3 & $\begin{array}{l}\text { Indonesians can benefit from contact with native } \\
\text { speakers of English in terms of culture and } \\
\text { education. }\end{array}$ & $31.40 \%$ & $65.70 \%$ & $2.90 \%$ & $0 \%$ \\
\hline Statement 6 & $\begin{array}{l}\text { I like native speakers' culture such as movies and } \\
\text { music. }\end{array}$ & $28.60 \%$ & $68.60 \%$ & $3 \%$ & $0 \%$ \\
\hline
\end{tabular}

Furthermore, table 3 above shows the number of learners who prefer living with native speakers of English. Leaners tend to have a direct communication with native speakers of English in the learning process. Not only learning with native but also having conversation with native speakers of English. Learners believe that have a direct contact with native speakers may improve their ability in speaking English. With native speakers of English, they also can acquire their pronunciation. Even though, according to Sung (Sung, 2016), it is argued that continued obedience to native-speaker norms in pronunciation might have a negative impact on preparing learners for international use of English as lingua franca.

Table 4. The questionnaire results frequency of experience living in an English-speaking country

\begin{tabular}{llrrrr}
\hline No & Statements & Strongly Agree & Agree & Disagree & Strongly Disagree \\
\hline Statement 1 & $\begin{array}{l}\text { If possible, I want to live in English-speaking } \\
\text { countries. }\end{array}$ & $31 \%$ & $57.10 \%$ & $11.40 \%$ & $0 \%$ \\
\hline
\end{tabular}

Since the table 1 shows that most of Indonesian learners want to study abroad, table 4 seems to have a balance with that. According to the question 'If possible, I want to live in English-speaking countries', the data shows a high percentage of students who agree to the question. The learners tend to focus in improving their speaking skill to live abroad outside Indonesia. The English-speaking countries such as United Kingdom or the closest one to Indonesia which is Australia seems interact students to improve their speaking skill.

Table 5. The questionnaire results frequency of English conversation in everyday life

\begin{tabular}{|c|c|c|c|c|c|}
\hline No & Statements & Strongly Agree & Agree & Disagree & $\begin{array}{l}\text { Strongly } \\
\text { Disagree }\end{array}$ \\
\hline Statement 1 & $\begin{array}{l}\text { To succeed in Indonesia, English ability is } \\
\text { necessary. }\end{array}$ & $29 \%$ & $65.70 \%$ & $5.70 \%$ & $0 \%$ \\
\hline Statement 2 & $\begin{array}{l}\text { Those with a good command of English are } \\
\text { given preferential treatment in Indonesian } \\
\text { society. }\end{array}$ & $11.40 \%$ & $80 \%$ & $8.60 \%$ & $0.00 \%$ \\
\hline Statement 3 & $\begin{array}{l}\text { I envy Indonesians who have superior English } \\
\text { proficiency. }\end{array}$ & $25.70 \%$ & $48.60 \%$ & $22.90 \%$ & $3 \%$ \\
\hline
\end{tabular}


It can be stated that most of learners agree that in Indonesia, English ability is needed to be successful. With this point of view, encourage the learners to master English. It is proved with 'Those with a good command of English are given preferential treatment in Indonesian society'. The other factors that may encourage them are the next questions. Being envy to who has higher proficiency in English may motivate them to learn English. With wrong pronunciation occur, students tend to be shy but it may improve their ability in pronounce the words. They can learn the correct pronunciation with the native speaker that they meet or just watch video on YouTube since they are more interested learning with native speakers of English.

Table 6. The questionnaire results frequency of focused pronunciations study

\begin{tabular}{|c|c|c|c|c|c|}
\hline No & Statements & $\begin{array}{l}\text { Strongly } \\
\text { Agree }\end{array}$ & Agree & Disagree & $\begin{array}{l}\text { Strongly } \\
\text { Disagree }\end{array}$ \\
\hline Statement 1 & $\begin{array}{l}\text { I am concerned about my pronunciation when } \\
\text { communicating in English. }\end{array}$ & $20 \%$ & $60.00 \%$ & $20.00 \%$ & $0 \%$ \\
\hline Statement 2 & $\begin{array}{l}\text { Pronunciation is an important part of English } \\
\text { ability. }\end{array}$ & $40.00 \%$ & $57 \%$ & $0.00 \%$ & $2.90 \%$ \\
\hline Statement 3 & $\begin{array}{l}\text { I can mimic native speakers' English } \\
\text { pronunciation. }\end{array}$ & $11.40 \%$ & $48.60 \%$ & $37.10 \%$ & $3 \%$ \\
\hline Statement 4 & $\begin{array}{l}\text { I can mimic any sound even when its meaning } \\
\text { is not clear. }\end{array}$ & $8.60 \%$ & $54.30 \%$ & $37 \%$ & $0 \%$ \\
\hline
\end{tabular}

Most of the learners are concerned with their pronunciation skill in English. They think that pronunciation is important in the learning of English. With this kind of point of view, may encourage learners to have better pronunciation that lead to no misunderstanding because of wrong pronunciation. We can utter sentences with various vocabulary and correct grammar, however will still not be able to carry our messages or meaning successfully because we mispronounce words or use incorrect intonations when speaking (Ke \& Cahyani, 2014).

Those factors are the most influent factors to Indonesian learners in English pronunciation. The factors such as the reason in learning English, the important of pronunciation, and how long they are studying English influence their pronunciation. Indonesian learners in this research, they are fifth semester students of English department have been studying English more than ten years since they were elementary school. It can be avoided since English is a must for them.

\section{Distribution of Pronunciation Rating}

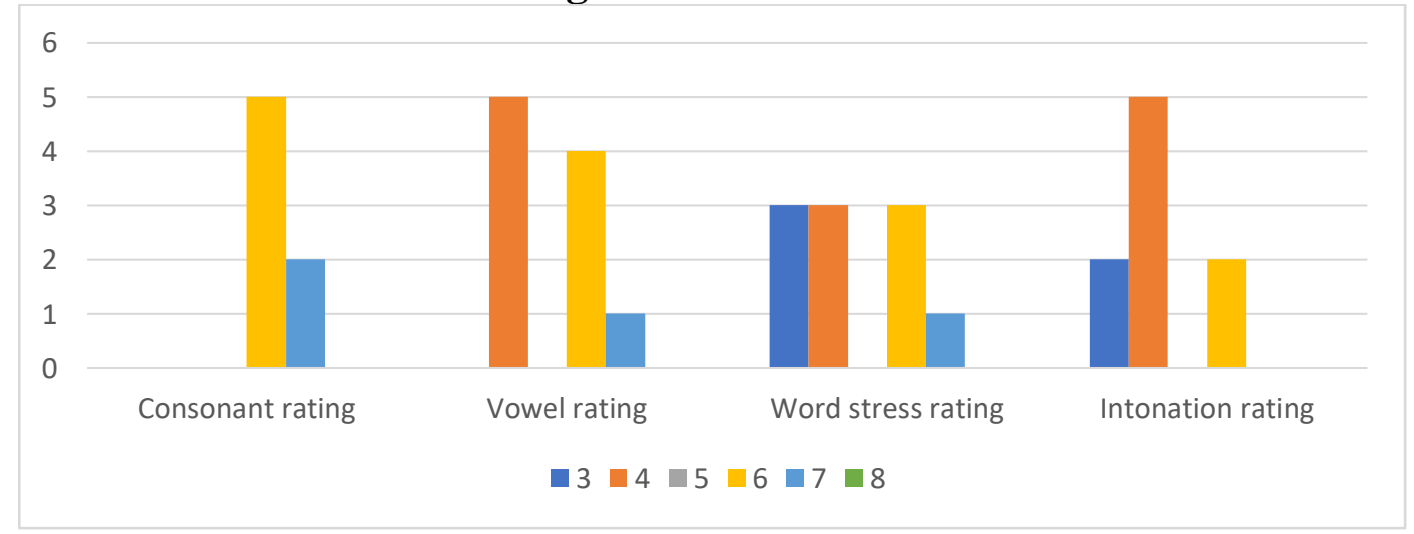

Figure 1. Distribution of Pronunciation Rating

Based on the research conducted, there is no significant difference between individual. The students have similar pronunciation rating in consonant, vowel, word stress, and intonation. Meanwhile, the result of the study shows that students who have accurate in vowel, usually they also have accurate in the term of consonant. Students who have correct word stress also have appropriate intonation. Indonesian learners tend to have accurate consonant rating than vowel rating. According to the 
previous questionnaire which shows students tend to follow the pronunciation as native-like, it affects to the pronunciation rating of them. Most of them have score more than five in the pronunciation rating. Even there are learners who have score of seven in the terms of consonant rating, vowel rating, and word stress rating.

\section{Conclusion}

In conclusion, the result of this study showed the factors affecting Indonesian learners' English pronunciation. The factors are the length of English study time, the reason why they are studying English (to get a good grade in order to study abroad), job opportunities, having a contact with native speakers of English, and their point of view to the important of pronunciation. Furthermore, the result also showed that most of the learners have similar pronunciation rating. Most of them have high rating in the terms of consonant, vowel, word stress, and intonation. The word stress rating is seen as the lowest rating, while the consonant rating is the highest. Students who have high rating in the consonant tend to have high rating in the vowel, students who have high rating in the word stress tend to have high rating of intonation. From the findings also indicate that most of Indonesian learners try to imitate or copy the way the native speakers of English speak, or it can be called that they want to be a nativelike pronunciation.

The aims of this study are to gain information about what factors that affect Indonesian learners' English pronunciation and pronunciation rating. Since pronunciation is important as a part of speaking skill. Incorrect pronunciation may produce misunderstanding massage. Thus, the teacher should give more pronunciation teaching.

\section{References}

Abadi, C. P. (2015). Developing Speaking Skill in EFL English Course. Journal on English as a Foreign Language, 5(2), 133. https://doi.org/10.23971/jefl.v5i2.373

Abdullah, M. Y., Hussin, S., \& Ismail, K. (2019). Implementation of flipped classroom model and its effectiveness on English speaking performance. International Journal of Emerging Technologies in Learning. https://doi.org/10.3991/IJET.V14I09.10348

Andrade, A., Pereira, S., \& Tolo, A. (2018). Teaching Speaking by Using Communicative Approach to Second Year Students of Lower Secondary School Oecusse. ISCE: Journal of Innovative Studies on Character and Education, 2(1), 84-92.

Cam, L., \& Tran, T. M. T. (2017). An evaluation of using games in teaching English grammar for first year English-majored students at Dong Nai Technology University. International Journal of Learning, Teaching and Educational Research, 16(7), 55-71. Retrieved from https://pdfs.semanticscholar.org/ea44/48f1c6cbb8dab7420abbd20a993a86728206.pdf

Doqaruni, V. R. (2015). Increasing Confidence to Decrease Reticence: A Qualitative Action Research in Second Language Education. The Canadian Journal of Action Research, 16(3), 42-60.

Gilakjani, A. P. (2016). English Pronunciation Instruction: A Literature Review. International Journal of Research in English Education, 1(1), 1-6.

Harmer, J. (2007). The Practice of English Languag Teaching. 394-409.

Hollins, E. R. (2011). Teacher preparation for quality teaching. Journal of Teacher Education. https://doi.org/10.1177/0022487111409415

Hwang, E. (2008). Factors affecting Korean learners' English pronunciation and comprehensibility. ENGLISH TEACHING ( 영어교육), 63(4), 3-28.

Ke, I. C., \& Cahyani, H. (2014). Learning to become users of English as a Lingua Franca (ELF): How ELF online communication affects Taiwanese learners' beliefs of English. System. https://doi.org/10.1016/j.system.2014.07.008

Mitchell, K. M., \& Clark, A. M. (2018). Five steps to writing more engaging qualitative research. 
International Journal of Qualitative Methods. https://doi.org/10.1177/1609406918757613

Musthafa, B. (2001). Communicative language teaching in Indonesia issue of theoretical assumption and challenges in the classroom practice. Journal of Southeast Asian Education, 2.

Pramjit, B., \& Dhillon, S. (2016). Does Mother Tongue Affect the English Pronunciation? International Journal of Languauge, Education, Humanities, and Innovation.

Quinn Patton, M., \& Cochran, M. (2007). A Guide to Using Qualitative Research Methodology. In Medecins Sans Frontieres. Retrieved from http://msf.openrepository.com/msf/handle/10144/84230

Riadil, I. G., Mar'ah, A. K., \& Romadhon, F. (2019, September). INSERTS USED BY ARIANA GRANDE OF INTERVIEW IN JIMMY FALLON TALK SHOW. In UNNES International Conference on ELTLT, (pp. 90-99).

Riadil, I. G. (2020). A Study of Students' Perception: Identifying EFL Learners' Problems in Speaking Skill. International Journal of Education, Language, and Religion, 2(1), 31-38.

Riadil, I. G. (2020). AN ANALYSIS OF ENGLISH MODALS IN MODAL VERB PHRASE STRUCTURES IN EDUCATIONAL ESSAYS OF 'SHERRY JOHNSON'AND 'TAMJID MUJTABA'. Jurnal Pendidikan Bahasa, 9(1), 131-142.

Riadil, I. G. (2020). DOES ORAL PRESENTATION AFFECT THE DEVELOPMENT OF THE STUDENTS'ABILITY TO SPEAK IN EFL CLASSROOM? Social Sciences, Humanities and Education Journal (SHE Journal), 1(2), 13-21.

Riadil, I. G. (2020). Tourism Industry Crisis and its Impacts: Investigating the Indonesian Tourism Employees Perspectives' in the Pandemic of COVID-19. Jurnal Kepariwisataan: Destinasi, Hospitalitas dan Perjalanan, 4(2), 98-108.

Richards, J. C., \& Schmidt, R. (2010). Longman dictionary of language teaching \& applied linguistics. In Proceedings of the 21st Asian Pacific Weed Science Society (APWSS) Conference, 2-6 October 2007, Colombo, Sri Lanka. Retrieved from http://images.pcmac.org/Uploads/JeffersonCountySchools/JeffersonCountySchools/Departments/ DocumentsSubCategories/Documents/English - Dictionary of Language Teaching and Applied Linguistics.pdf

Sung, C. C. M. (2016). Exposure to multiple accents of English in the English Language Teaching classroom: from second language learners' perspectives. Innovation in Language Learning and Teaching, 10(3), 190-205. https://doi.org/10.1080/17501229.2014.936869

Zein, M. S. (2017). Elementary English education in Indonesia: Policy developments, current practices, and future prospects: How has Indonesia coped with the demand for teaching English in schools? English Today, 33(1), 53-59. https://doi.org/10.1017/S0266078416000407 